\title{
The Effective Role of Literary Texts in Developing Paragraph Writing
}

\author{
Mahir El-Rufai Babikir Ibrahim Salim
}

Jazan University / Saudi Arabia. English Language Department

Supervised by/ Dr. Abd Al-Mahmoud Idris Ibrahim \& Dr.Nada Sid Ahmed Eljack

\begin{abstract}
The study attempts to investigate the teachers" ability in exploiting literary texts, in particular, Sudanese short stories in promoting and developing writing skills and to discover to what extend are the students able to deal with certain literary texts, (Sudanese Short Stories) as a technique of paragraph writing. The focus will be on paragraph writing at Sudanese Secondary level in particular $2^{\text {nd }}$ year. The researcher tries to attain the aims of the study by having two tests for students. The two tests were given thirty minutes. The first test was meant to measure the students" abilities and standards in writing a proper paragraph.
\end{abstract}

Keywords: literary texts, short stories, developing, authentic, students.

\section{Introduction}

Using literary texts in developing writing a paragraph is important since it provides students with authentic material, motivation and enriches thinking process as Brumfit \& Carter stated (1986.: 15) " a literary text is authentic text, real language in context, to which we can respond directly "Moreover, Collie \&Slater (1994: 5) said that "the formation and function of sentence, the variety of possible structures, and the different ways of connecting ideas "

This means that students are exposed to many features of written language.

Furthermore, Widdowson, cited in Lazar, (1993:18) confirmed that learners are encouraged to familiarize themselves with different language uses, forms which is essential for the students ,linguistic development. Thus, they can appreciate the richness and variety of language and become more sensitive to the features of it.

Concerning short stories as Hill (1994:15) stated that their basic criteria in choosing a text. These are represented in the needs and the students ${ }^{\text {ee }}$ abilities, the linguistic and stylistic level of the text and the background information required for true appreciations of the text. Therefore, the teacher should decide the readability of the text by choosing graded or simplified stories which is very practical way and it is highly suggested for the sake of suiting the text with the level of the students. The researcher shaded the light on; by saying short stories are important for promoting students ${ }^{\text {ee }}$ language abilities. But it is not an easy job to use them in public schools due to overcrowded classes, overloaded syllabus and limited time. But short stories are the most suitable to be used in government schools since they are short, and contain simple literary features, one plot, a few characters and there is no detailed description of setting. Therefore, short stories are the most suitable literary genre to teach a paragraph.

This was confirmed by Poe ( cited in Abrams 1970:158) who stated " as a narrative that can be read at one sitting of from one-half hour to two hours, and that is limited to : a certain unique or single effect, to which every detail is subordinate ". In addition, Collie \&Slater (1991: 196) mentioned four advantages of using short stories in developing writing. First, they are not long so that they can be covered in one session. Second, they are not complicated for students to use them in their writing. Third, short stories have a variety of choice of different interests and tastes. Finally, they can be used for all levels (beginners to advance Levels). The teacher plays an essential role in choosing a suitable text to use in class, and help his students understand the text with various activities. The shortness of the story can help students to read and understand and it will give them feelings of self-confidence and achievement.

Ibrahim (2012) carried out M.A in "Investigating the difficulties experienced by English Language Learners in writing paragraph". Sudan University of Science and Technology. The researcher asked whether the students encountered linguistics problems in writing paragraph and the causes led to these problems. He hypnotizes that their poor standard in the basic skills of writing are the main causes of these difficulties to write a paragraph. The study showed that the students ${ }^{\text {ee }}$ inabilities in writing paragraph properly. And this was due to mother tongue interference and the teachers who lacked training.

\section{Setting and Population}

The setting of the paper was a Sudanese governmental secondary school for boys in Khartoum State. The population of the paper was 80 students in $2^{\text {nd }}$ year at secondary stage. They were divided into two groups as experimental and control group All of them are boys , at the same age and school but they are randomly chosen.

The tools used in the study were two tests pre -test and posttest and each one was different from the other .That means, a pre was given to check the studentse ability and knowledge in writing a paragraph while the second was a programmed one and the students were given a lot of grammatical items 


\section{International Journal of Science and Research (IJSR) \\ ISSN (Online): 2319-7064 \\ Index Copernicus Value (2013): 6.14 | Impact Factor (2015): 6.391}

and information about paragraph writing. That is to say, the students were given an idea about the steps and ways of paragraph writing.

Tools ${ }^{\text {ee }}$ Reliability and Validity refer to the data collection procedure. In order to measure the reliability of the tools used in the study, the researcher followed these points:

The (SPSS) is used to analyze the data.

Two tests were distributed to (80) students. Instruments and Procedures: Data Collection:

The data was collected through questionnaire and tests.The students were chosen from one school and given the same test. In each class (40) students did the test. Then, the papers were collected to be corrected and evaluated.

The collected data through the teachers ${ }^{e e}$ questionnaire, the pre- and the post-tests (experimental and control group) which checked the studentse performance in writing a paragraph, were analyzed in this part. A comparison between the students ,competence in writing a paragraph and the teachers ${ }^{\text {ee }}$ opinions about their students, abilities in writing a paragraph, was carried out . Besides the teachers ${ }^{\text {ee }}$ opinions in exploiting literature to promote students „abilities. The analyzed data of the tests and questionnaire was represented in tables and histogram as follows:

1) Your students face difficulties in writing a paragraph.

\begin{tabular}{|c|c|c|c|c|}
\hline $\begin{array}{c}\text { Cumulative } \\
\text { Percent }\end{array}$ & $\begin{array}{c}\text { Valid } \\
\text { Percent }\end{array}$ & Percent & Frequency & \\
\hline 34.3 & 34.3 & 28.6 & 24 & Agree \\
\hline 48.6 & 14.3 & 11.9 & 10 & Disagree \\
\hline 98.6 & 50 & 41.7 & 35 & Strongly agree \\
\hline 100 & 1.4 & 1.2 & 1 & Strongly disagree \\
\hline & 100 & 83.3 & 70 & Total \\
\hline & & 16.7 & 14 & System \\
\hline & & 100 & 84 & Total \\
\hline
\end{tabular}

Table 1: Teacher's response

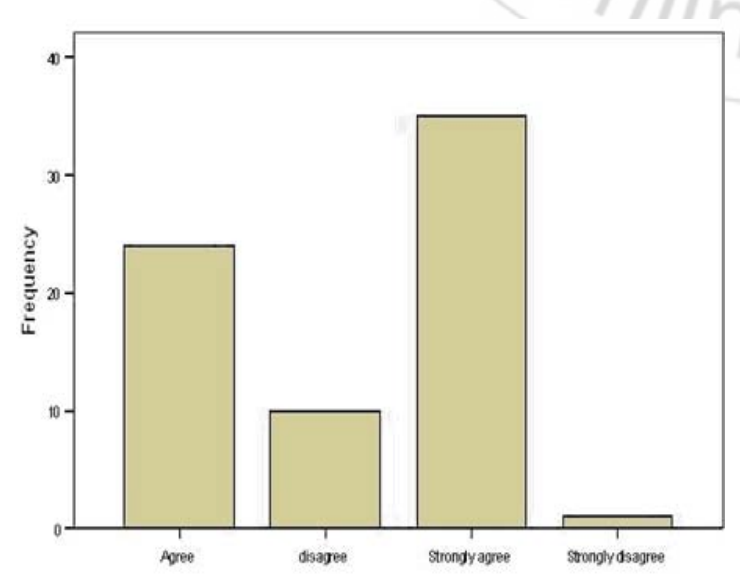

Figure 1: Teachers ${ }^{e c}$ response which of the experimental group.

2) English literature (an extract) is used as a theme for writing a paragraph.

Teachers "response Table 2

\begin{tabular}{|c|c|c|c|c|c|}
\hline $\begin{array}{c}\text { Cumulative } \\
\text { Percent }\end{array}$ & $\begin{array}{c}\text { Valid } \\
\text { Percent }\end{array}$ & Percent & Frequency & & \\
\hline 41.4 & 41.4 & 34.5 & 29 & Agree & Valid \\
\hline 55.7 & 14.3 & 11.9 & 10 & Disagree & \\
\hline 91.4 & 35.7 & 29.8 & 25 & Strongly agree & \\
\hline 100 & 8.6 & 7.1 & 6 & Strongly disagree & \\
\hline & 100 & 83.3 & 70 & Total & \\
\hline & & 16.7 & 14 & System & Missing \\
\hline & & 100 & 84 & Total & \\
\hline
\end{tabular}

Figure 2: Teachers $^{\text {ee }}$ response

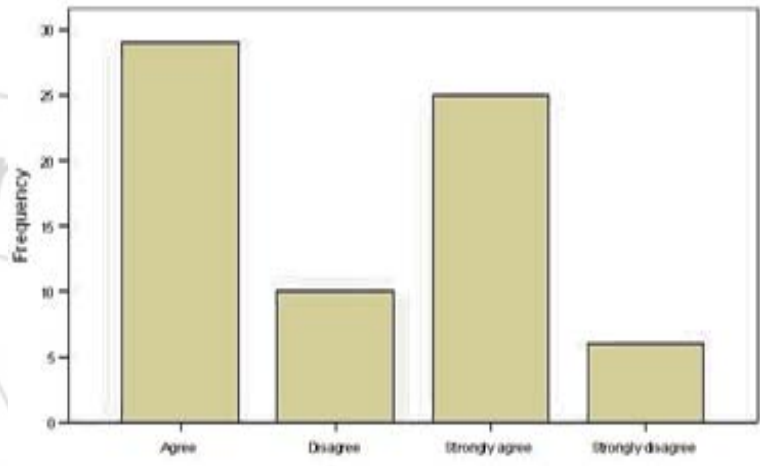

2-According to (table 2\&Fig2) a lot of teachers stated that literature (extract) can be used in teaching a paragraph. But the students ${ }^{\text {ee }}$ achievement in the pre-test did not reflect this.

3) Sudanese Short Stories are exploited in writing a paragraph.

Teachers "response Table 3

\begin{tabular}{|c|c|c|c|c|c|}
\hline $\begin{array}{c}\text { Cumulative } \\
\text { Percent }\end{array}$ & $\begin{array}{c}\text { Valid } \\
\text { Percent }\end{array}$ & Percent & Frequency & & \\
\hline 47.1 & 47.1 & 39.3 & 33 & Agree & Valid \\
\hline 55.7 & 8.6 & 7.1 & 6 & Disagree & \\
\hline 98.6 & 42.9 & 35.7 & 30 & Strongly agre & \\
\hline 100 & 1.4 & 1.2 & 1 & $\begin{array}{c}\text { Strongly } \\
\text { disagree }\end{array}$ & \\
\hline & 100 & 83.3 & 70 & Total & \\
\hline & & 16.7 & 14 & System & Missing \\
\hline & & 100 & 84 & Total & \\
\hline
\end{tabular}

1-As it was shown in (table1\&Fig1), nearly all the teachers strongly confirmed that their students face difficulties in writing a paragraph. Their opinions were clearly seen in the performance of their students in the two tests, especially 


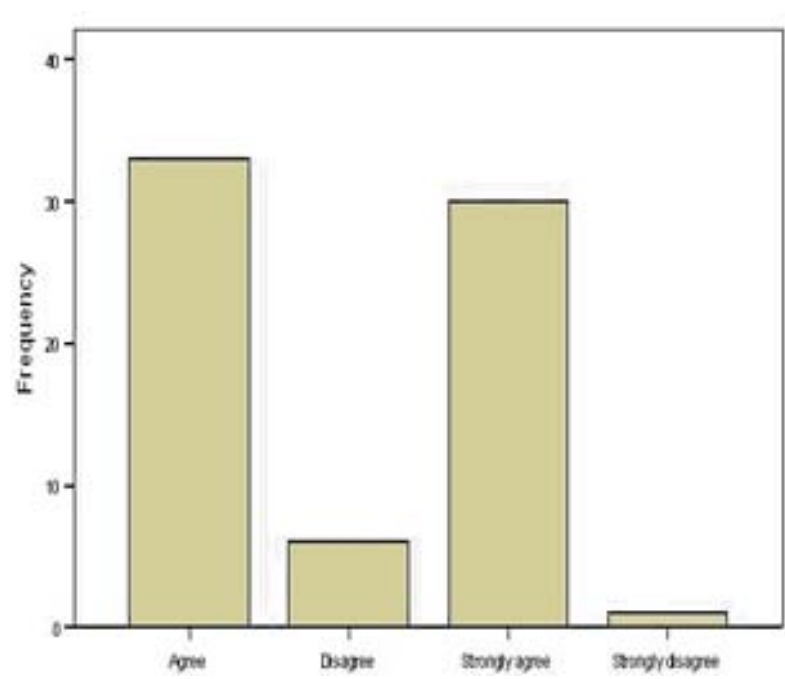

Figure 3: Teachers ${ }^{\text {ee }}$ response $\left(5^{\text {th }}\right.$ Ed). Glasgow: Cambridge University Press.

[4] Hill, Jenifer. (1994). Using Literature in Language Teaching. ELT Journal London. Macmillan.

[5] Lazar, Gillan. (1993). Literature and Language Teaching. Cambridge: Cambridge University Press.

[6] Mallet M. (2005). The Primary English EncyclopediaThe heart of The Curriculum. Rout Ledge London \&New York

3- The teachers' responses (table 3\&Fig3) agreed on adopting literature (Sudanese Short stories) to teach a paragraph. In comparing their answers with the students' writing abilities (experimental group), it was obvious that the teachers are in lack of the required training. Exploiting literature (extract from Sudanese Short Stories) can stimulate students ,imagination since these stories are related to their cultural background.

\section{Conclusion}

(Brumfit and Carter (1986) state that: "As far as 'literary studies are concerned, students also acquaint themselves with the nature of literary discourses and therefore are studying literature in a very primary and essential sense."

The study is an attempt and a contribution in an area that deals with literature which had been neglected by many educational centres. This study. The findings of the analysis of the study have confirmed the findings of the previous studies, in particular. The future researches may support or extend the findings concerning the importance of literature on performance, thinking and education of students. That is to say, the teaching of literature should be included in all educational curricula for its necessity and importance.

\section{Findings}

The analysis of the results of the study provided the following findings:

1) Involving short stories in teaching to write a paragraph is really useful.

2) It also helps the students to know more vocabulary and linguistic expressions.

3) The tests given to the students were more useful and beneficial.

\section{References}

[1] Abrams, M.H. (1970). Glossary of Literary Terms. New York: Rinehart.

[2] Brumfit, C.J. \&Carter, R.A. (1986). Literature and Language Teaching. Oxford: Oxford University

[3] Collie, J., \&Slater, S. (1990).Literature in the Classroom. 